\title{
Music as a cultural remedy: Exploring the role of music as a way for Asian-American youth to navigate their dual identity in the socio-political context following the COVID-19 outbreak
}

\author{
Cho, Lauren Hyunseo \\ Independent Researcher, Korea International School, Seoul, South Korea
}

\begin{abstract}
Adolescence is characterized by the constant struggle to establish one's identity. Music is a medium for adolescents to express their social identity and group belongingness. Therefore, minority groups in multicultural societies often exhibit unique music preferences. AsianAmerican youth experience conflict between their Asian and American identities, which adds to the stress of identity formation. Accordingly, this study examined the music preferences of Asian-American youth and its role in determining their socio-cultural identity. Further, considering the existing stereotypes regarding Asians and the negative perceptions of Asians caused by the COVID-19 outbreak, this study examined if the current socio-political context surrounding COVID-19 influenced Asian-American youth's identity expression and music choices. Employing a qualitative phenomenological approach, in-depth interviews were conducted with seven participants aged 15-24 years. Four major themes were extracted, with two about the positive and negative aspects of being Asian-American and two about the personal and global relevance of music. Findings revealed the struggle between the Asian and American identities of the youth. Participants reported that the COVID-19 outbreak had led to negative perceptions about Asians or that it had intensified the pre-existing negative stereotypes. All participants considered music as a mode of expressing their Asian identity and their preferences tended to match those of their peer group. These findings highlight the lived experiences of Asian-American youth and their identity conflicts, and they confirm the social function of music in this process. These results can be used to develop counseling interventions for Asian-American youth during identity formation.
\end{abstract}

Keywords: Asian; identity formation; music; phenomenology; youth

\section{Introduction}

It is widely accepted that adolescence and early adulthood is a period of change, characterized by developmental tasks pertaining to identity formation (Erikson, 1968). According to Marcia $(1966,1980)$, individuals pass through four stages of identity formation, namely, diffusion, foreclosure, moratorium, and achievement. Often spanning from early adolescence to early adulthood, these four stages entail exploring different identities, accepting identities based on social expectations, tentative acceptance of an identity following exploration, and committing to an identity after having explored different alternatives, respectively (Marcia, 1980). Thus, across all cultures, the period of youth (15-24 years; United 


\section{3-05 September $2021 \quad$ Prague, Czech Republic}

Nations Department of Economic and Social Affairs, n.d.) is often characterized by this constant struggle to establish one's identity. There is substantial research on factors that contribute to this process, music being one of them.

\subsection{Music and youth}

Music plays a pivotal role in our life. In his review of research on the role of music in adolescent development, Miranda (2013) acknowledged that there is substantial research evidence on the linkages between music and important factors such as emotion, personality, mental health, identity, self-image, and social behavior, among others. Studies suggest that the salience of music in adolescents' life stems from its ability to fulfill the developmental tasks of adolescence (Bleich et al., 1991; Miranda \& Claes, 2009), such as establishing one's belief system, exhibiting socially-appropriate behavior, achieving social and emotional independence, and developing and maintaining peer relationships (Kirchler et al., 1993; Palmonari et al., 1990). Music is also viewed as a medium for individuals' expression of their self-image and management of others' view of them (North et al., 2000; North \& Hargreaves, 1999), and it contributes to the development of adolescents' self-concept (Fletcher, 2015; Miranda, 2013). Indeed, there is a rich body of research confirming the importance of music in the life of youth. However, very few studies have employed a qualitative approach to examine adolescents' perspective on how they express their identity through music. Therefore, the primary aim of the present study was to explore if adolescents' music preferences were a medium to express their socio-cultural identity.

Further, according to Hargreaves and North (1997) among its multiple functions, the social role of music is its most salient function. Rentfrow and Gosling (2006) reported that music preferences are the medium through which individuals negotiate their social image. Additionally, individuals judge others' personality and values based on their music preferences. Thus, individuals' music choices are a way to represent their personality, beliefs, values, status, and group belongingness (North \& Hargreaves, 2008). Thus, individuals' music choices act as a "badge" that helps establish their membership of a social group (Dolfsma, 1999). It is then imaginable that this "identification" function would become more relevant in a multicultural society because one's music choice becomes a medium for expressing one's cultural affiliation. According to Phinney (1990), this explains why young individuals belonging to ethnic minorities tend to express preferences for music from their heritage. On the flip side, ethnic music also acts as a medium for cultural learning and is therefore preferred by adolescents when their identity is taking shape (Saether, 2008).

Relatedly, previous studies conducted in the UK reported that the musical preferences of majority and minority groups differed substantially (Gregory, 1997; Russell, 1997). AsianAmericans are a minority group in the US, whose socio-cultural identity is an amalgamation of their Asian lineage and American upbringing. As explained in the next section, individuals belonging to this group often exhibit unique characteristics and identity conflicts owing to the mixing of their two cultural identities.

\subsection{Identity of Asian-American Youth}

Defined as Americans (by birth or naturalization) with Asian ancestry (Budiman \& Ruiz, 2021), the "Asian-American" community is composed of 6 predominant sub-ethnicities: Chinese, Indian, Filipino, Vietnamese, Korean, and Japanese (Pew Research Center, 2012). They comprise one of the fastest growing minority groups in the US. The Asian population has 


\section{3-05 September $2021 \quad$ Prague, Czech Republic}

doubled from 2000 to 2019, and it is expected to cross 46 million individuals by 2060 (Budiman $\&$ Ruiz, 2021). This population comprises a large proportion of young individuals; in 2019, the median age of Asian-Americans was 34 years (vs. 38 years as the national median), with the median age of US-born Asian-Americans substantially lower than that of the national median (19 years vs. 36 years). A major chunk of this large subgroup of young Asian-Americans could be going through the identity struggles that are characteristic of their age-group. The added stressors stemming from their mixed cultural identity warrant in-depth research on the experiences of Asian-American youth.

In terms of cultural identity, the Asian population in America has often experienced cultural stereotypes, especially those perpetuated by media images (Zhang, 2010). For instance, in mainstream media, Asian women are either depicted as effeminate, introverted, obedient, and hypersexualized, or as villainous, "ruthless dragon ladies" (Lee \& Joo, 2005; Park, et al., 2006). In contrast, Asian men are depicted as martial artists, with poor English, culturally ignorant, and introverted (Lee \& Joo, 2005; Yuen et al., 2005; Zhou, 2004).

In the larger social sphere, Americans often perceive Asians as the "model minority", characterized as who are hardworking, intelligent, nerdy, highly educated, high achievers, and polite (Jung, 2021, Kim, 2021; Lee \& Joo, 2005; Taylor et al., 2005). They are also seen as "perpetual foreigners" who are considered non-American despite being born and/or raised in America (Zhou, 2004). As a result of their perceived passiveness, apolitical stance, and politeness (Pew Research Center, 2012), several studies have reported that Asian-Americans have historically been prone to violence, discrimination, and bullying (Pew Research Center, 2012; Suzuki, 2002; Taylor et al., 2005). However, owing to the "model minority" image, when compared to other ethnic minorities in America (e.g., Hispanic and Black Americans), AsianAmericans had relatively fewer experiences of racial discrimination until recently. For instance, a 2012 survey conducted by the Pew Research Centre found that only 1 in 5 individuals had experienced discrimination owing to their Asian ethnicity, and only 1 in 10 had experienced name-calling (Pew Research Center, 2012). Participants of this survey added that, even when they did experience racialized behavior, it was to their advantage because they were assumed to be hardworking and intelligent.

Though the "model minority" image could pose its advantages, and it may function as a "self-fulfilling prophecy of Asian American exceptionalism" (Lee \& Zhou, 2014), it comes with its own baggage, especially for the youth. Asian youth (in America or otherwise) are expected to excel in academics, and to be studious and hardworking (Kim, 2021; Lee \& Joo, 2005; Lee \& Zhou, 2014, Suzuki, 2002). This pressure leads to several negative effects on their social life and mental health, including loneliness and alienation (Lorenzo et al., 2000), depression, and stress (Jung, 2021; Lorenzo et al., 2000). These problems often go unreported, and as a result, Asian-American youth have several unmet mental health needs. Therefore, it is imperative to understand the personal experiences of Asian-American youth as they negotiate these social pressures and the process of identity formation simultaneously. Considering the research on the role of music preferences in one's identity formation and expression presented in the preceding section, and the unique identity of Asian-Americans discussed here, this study aimed to examine the lived experiences of Asian-American adolescents in an attempt to understand if their music preferences influenced their identity and vice-versa. 


\section{3-05 September $2021 \quad$ Prague, Czech Republic}

Further, the COVID-19 pandemic has brought about extensive changes globally. With media reports, statements made by politicians, and other sources of information suggesting that the spread of the disease started from Asia, individuals of Asian ethnicity have reported instances of increased prejudice and hate crimes against them (Chen et al., 2020; Croucher et al., 2020; Ruiz et al., 2021; Wu et al., 2021). With these changes in the social perception of Asians moving away from the "model minority" view, the present study aimed explored if Asian-American adolescents' expression of their Asian identity through their music preferences was influenced by the socio-political changes brought about by COVID-19 pandemic. Thus, the present study had two core objectives:

1. To examine if the music preferences of Asian-American youth are a mode of expression of their unique cultural identity.

2. To examine if the socio-political changes that have occurred following the COVID-19 pandemic influence the music preferences and identity expression of Asian-American youth.

\section{Methodology}

\subsection{Research Design}

Considering the objectives of the study, a mixed-method design was employed. Specifically, as it was first imperative to understand the music preferences of Asian-American youth, a preliminary survey was conducted to collect quantitative data. Subsequently, the qualitative approach of phenomenology was employed to explore the lived experiences of Asian-American youth with reference to the two objectives. Phenomenology was chosen because it facilitates "the study of structures of consciousness as experienced from the firstperson point of view" (Smith, 2018).

\subsection{Sampling}

Phenomenology requires the selection of research participants who meet predefined criteria, which ensure that the selected participants "have shared an experience, but vary in characteristics and in their individual experiences" (Moser \& Korstjens, 2018). Considering the focus of the present study, the following inclusion criteria were used to select participants: (a) belonging to the Asian-American ethnic group [defined as Americans (by birth or naturalization) with Asian ancestry (Budiman \& Ruiz, 2021)], (b) being aged 15 to 24 years [i.e., fitting the UN's definition of "youth" (UNDESA, n.d.)], and (c) currently residing in the US. Additionally, the potential participants were required to be able to communicate in English, have access to a stable internet connection to enable communication with the researcher, and voluntarily agree to participation in the study. To ensure that the sample represented varied individual experiences and perspectives, the qualitative research principle of divergence was employed to select participants with different background characteristics. In doing so, the researcher sought participants who belonged to the six different sub-ethnicities within the category of Asian-Americans (Pew Research Center, 2012). Additionally, participants from different geographical locations in the US, and both males and females were selected.

The number of participants was determined based on the qualitative research principle of data saturation. Data saturation is defined as "the collection of qualitative data to the point where ... new data yields redundant information" (Moser \& Korstjens, 2018). To determine 


\section{3-05 September $2021 \quad$ Prague, Czech Republic}

data saturation, data collection and analysis was conducted simultaneously. After the 7th interview, no new themes emerged, therefore, it was decided that data saturation had been achieved. Thus, the final sample comprised 7 Asian-American youth. Their characteristics have been presented in Supplemental Tab. 1.

\subsection{Research Procedure}

Participants were contacted via email, providing them an explanation of the study, its objectives, their rights as a participant (confidentiality, voluntary participation, and option to withdraw at any time), and a link to the online survey (Google Forms). They were informed that, if they proceeded to complete the preliminary survey, it was indicative of their provision of informed consent. At the end of the survey, they were asked if they would be willing to participate in the in-depth interview. If they agreed, the in-depth interview was scheduled at a mutually agreed time. As the study was conducted during COVID-19 and the participants resided in the US, the interviews were conducted via video-calling sessions conducted on the Zoom platform. After seeking participants' permission, the interviews were video recorded for later transcription and analysis.

\subsection{Tools}

\subsubsection{Preliminary survey}

The preliminary survey was used to gather background information about the AsianAmerican youth, their peer group, and their music preferences. The survey was created based on a literature review on music preferences, with items adapted from the Music Preference Questionnaire (MPQ-R) developed by Urs (2003). The information collected from the survey was triangulated with the qualitative data to help interpret the results better.

\subsubsection{In-depth interview}

The qualitative data were collected using an in-depth interview conducted via the videocalling platform Zoom. To achieve a deeper understanding of Asian-American youth, their perceptions of their own identity, their opinions about social perceptions regarding AsianAmericans, and the role of music in their life. An interview guide was developed to ensure that the conversations addressed the study's focus areas. It contained questions categorized into three sections. The first set of questions revolved around being Asian-American, participants' understanding of the Asian-American identity, social perceptions about Asian-Americans, and changes in this perception following the COVID-19 outbreak. The next set of questions pertained to the participants' music preferences. Though some aspects were already covered in the preliminary survey, the interview explored participants own preferences and the reasons for the same. The last set of questions aimed to extract information on how participants' music preferences helped them express their identity, taking into consideration the possible effects that their peers or the social perceptions about Asian-Americans had on this choice/expression. It also included questions on participants views about the position of Asian music/artists in the music industry. Throughout the interview, appropriate follow-up questions were asked to seek further clarification or elaboration from participants. Each interview lasted for about 30 minutes.

\subsection{Data Analysis}




\section{3-05 September $2021 \quad$ Prague, Czech Republic}

Data analysis was performed along with data collection to determine data saturation and to check if any additional information was required from participants. As data saturation was achieved by the 7th interview, data collection was then terminated. The analysis process was preceded by data transcription. Then, each transcript was read and re-read to familiarize oneself to the data. Subsequently, deductive thematic analysis was used to draw themes from the data. The first step of deductive thematic analysis involves reviewing the qualitative data multiple times while searching for keywords and key phrases that could correspond to a certain theme. These open codes were classified using color-coding to ensure an organized and clear thematic coding of the transcripts. The preliminary codes were then compared to identify similar codes that could be combined under a theme. The emerging themes were then labeled to derive the final themes. Finally, data from the quantitative survey and qualitative interviews were triangulated to develop a true understanding of the participants experiences and perspectives.

\section{Results}

Fig. 1 presents a map of the findings derived in this study. In this figure, themes and sub-themes have been indicated in boxes with solid and dashed lines, respectively. The results have been presented in two major sections, one on "Being Asian-American" and the other on "Music and the Asian-American Identity." The data-driven deductive analysis yielded four major themes (two under each heading).

Figure 1: Conceptual map of the findings on the identity of Asian-American youth

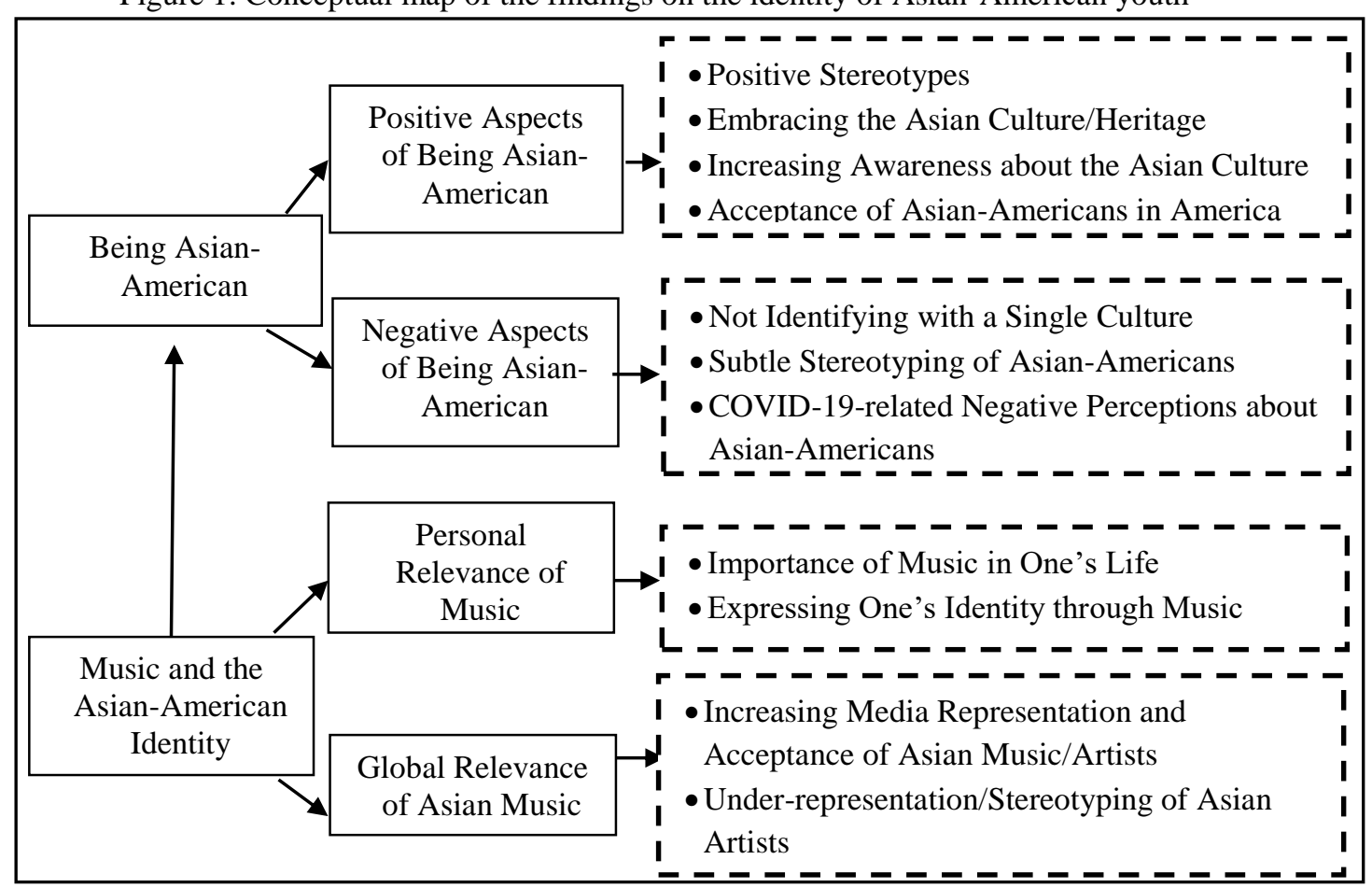

Note. Themes and sub-themes have been indicated in boxes with solid and dashed lines, respectively.

\subsection{Being Asian-American}

The themes under this section pertained to participants' lived experiences of being Asian-American. With reference to their perspectives on "being Asian-American" and the 


\author{
03-05 September $2021 \quad$ Prague, Czech Republic
}

social factors/changes in their experiences of being Asian-American, participants' narratives yielded two major themes: "Positive Aspects of Being Asian-American" and "Negative Aspects of Being Asian-American". Both these themes had four and three sub-themes, respectively.

\title{
3.1.1 Positive Aspects of Being Asian-American
}

This theme included participants positive experiences with being Asian-American, their opinions pertaining to accepting and embracing their identity as an Asian-American, and the desirable social stereotypes that were adaptive in nature. Overall, this theme revealed that participants enjoyed their dual identity as an Asian-American and that they cherished their Asian heritage. Further, they shared that they seldom had negative experiences related to their ethnicity, and saw their Asian identity as an opportunity to spread more awareness about the richness and multiplicity of the Asian culture. This theme had 4 sub-themes, which have been explained below.

\subsubsection{Positive stereotypes}

Participants described some positive stereotypes that they had experienced themselves or had witnessed vicariously in the society, such as being expected to be smart and good at academics because of their Asian ethnicity. For instance, while sharing that she experienced positive stereotyping in subtle ways, Participant 6 added,

"A lot of people think I will be good at math and science even though I am not... it feels good to be considered smart but that's a hard bar to reach all the time." Participant 6.

\subsubsection{Embracing the Asian culture/heritage}

This sub-theme encapsulated participants recounting how they grew increasingly more comfortable with and proud of their Asian culture and heritage in settling into their AsianAmerican identities. For example, Participant 2 shared how being Asian-American was a large part of her identity:

"... I have sort of been able to embrace it more, especially by consuming different kinds of media, really seeking out Asian-American identity books, or even just relating to peers or fellow Asian-Americans who are, like, first-second-third-generation and having them share their stories and experiences and being able to kind of relate and bond over that." Participant 2. American.

This theme revealed how participants cherished being Asian along with being

\subsubsection{Increasing awareness about the Asian culture}

Participants shared that a large part of being Asian-American revolved around not only embracing their own Asian culture, but also educating others of their culture. Participants shared experiences of where they help Americans know more about their Asian heritage, including, but not limited to, food, music, and language.

\subsubsection{Acceptance of Asian-Americans in America}

As an extension of the above sub-theme, participants also described how they observed increasing acceptance of Asian-Americans in the US. They attributed this increasing acceptance to American society's growing awareness of the hardships Asian-Americans face. 


\author{
03-05 September $2021 \quad$ Prague, Czech Republic
}

\title{
3.1.2 Negative Aspects of Being Asian-American
}

As suggested in the literature review, having a dual identity and being a minority group in the US came with its disadvantages. This became evident from participants' narratives about negative aspects of being Asian-American. This theme had 3 sub-themes, each of which are explained below.

\subsubsection{Not identifying with a single culture}

This was a salient theme for the participants, which evidenced their identity conflict. Participants explained how being Asian-American made them feel as though they could not identify with a single culture or background, but a fusion of both Asian and American cultures. Participant 3 said that he could not restrict his identity to simply one culture. He said,

“...being Asian-American is kind of being between two different worlds to me, so not being ... well... for me, not being completely Korean but also not being completely American. So it's kind of like not being accepted by either but kind of finding this niche of like Asian-Americans who kind of have the same experiences as me. I think that's what it is." Participant 3.

This identity conflict has important implications for the youth in this sub-culture, which have been discussed in Section 4.

\subsubsection{Subtle stereotyping of Asian-Americans}

As mentioned before, despite not having experienced serious acts of discrimination themselves, participants were perceptive of the subtle stereotypes that American society projected onto Asian-Americans. These included being alienated or designated as the "model minority." For example, Participant 3 said,

“[Americans] kind of have this stereotypical vision of just like an Asian immigrant who's kind of ... I don't know how to describe this, but like they don't really expect Asian-Americans to be kind of [in] the forefront of society and they kind of designate Asian-Americans as like the model minority ... so, um kind of like they do acknowledge that Asian-Americans work hard but they'll never like put us as equals and they kind of put glass ceilings above us" Participant 3 .

Participants also claimed that Asian-Americans were historically unaccepted in the US, and that they continued to be unaccepted in the current times. They added that these perceptions were largely driven by the media's portrayal of Asian-Americans. For example, Participant 3 elaborated on how the media negatively stereotyped Asian-Americans and failed spread awareness on the violence that the community is facing right now. A related sub-theme has been discussed in Section 3.x.x.x, with reference to the misrepresentation of Asian-Americans in the music industry.

\subsubsection{COVID-19-related negative perceptions about Asian-Americans}

This sub-theme revealed important findings pertaining to the second objective of this study. Participants claimed that the COVID-19 crisis brought up and amplified the pre-existing underlying animosity within the American society towards Asian-Americans. For instance, Participant 2 said, 


\author{
03-05 September $2021 \quad$ Prague, Czech Republic
}

“...now with COVID-19 a lot of people have starting turning and instead of seeing us as AsianAmerican or even just personalities or people, we very much get clumped into just "Chinese virus" which wasn't, um, which wasn't great, of course." Participant 2.

\title{
3.2. Music and the Asian-American Identity
}

With reference to the intersection between music preferences and identity expression, particularly in the context of the Asian-American identity, this study first explored the choices and peer-group composition of the participants using the survey. Though all participants considered music as a very important part of their life and they enjoyed listening to music, there were individual differences in their preferred genres and artists. Despite these differences, R\&B, Classical, and Pop (especially K-pop) music seemed to be most popular. Due to space limitations, these results have been summarized in Supplemental Tab. 2. The relevance of these results is presented by triangulating them with the qualitative findings. In delineating the connection between music and identity for Asian-American youth, two major themes were extracted from the data: "Personal Relevance of Music" and "Global Relevance of Asian Music." These themes had two sub-themes each.

\subsubsection{Personal relevance of music}

This theme pertained to the role/relevance of music in participants' life in general and in their identity formation and social belongingness.

\subsubsection{Importance of music in one's life}

In the survey and the interviews, participants talked about music playing an integral and important role in their lives. The primary reason was because of the amount of time participants spent listening to music in their daily lives (which ranged from 2-4 hours each day). Most participants listened to it during leisure activities or during school work. However, the interviews revealed specific functions that music fulfilled in their lives. One such function was facilitating peer relationships. Participants reported that music helped them establish friendships and connecting with others. As explained by Participant 3,

“...my friend groups are formed by music, um, so music not only kind of permeates my social life but it's something I listen to very often. Um, I've made a lot of new friends based on music taste as well, and I've introduced a lot of friends to music." Participant 3.

They also acknowledged the emotional function of music. Specifically, participants claimed that they enjoyed listening to music because they found good narratives in song lyrics. They felt as if they could express their emotions through their choice of music. For instance, when asked about why he considered music so important in his life, Participant 1 responded,

"You're able to listen to genres and artists that, uh, who have good songs and messages... so I feel like it's uh, it's um, a simple way to kind of escape reality and be in your own world." Participant 1.

\subsubsection{Expressing one's identity through music choices}

Participants talked about how music and songs produced by Asian-American artists helped them identify with their Asian culture and background. For example, Participant 3 said that he could relate more to Asian-American artists and their songs because they too belonged to minority groups. However, some participants reported that peer-pressure and the need to 


\section{3-05 September $2021 \quad$ Prague, Czech Republic}

"fit-in" limited their freedom to express their music choices openly, especially when they did not match those of their peers. This was evident from the survey results for Participant 2, 5 and 6 , whose peer group at least partly or completely comprised non-Asian-American individuals. It was interesting to note that all three participants tended to listen to the work of Caucasian artists more often. Participant 5 shared,

“... there's definitely a peer pressure that goes on, um... whenever I listen with friends I am pressured by myself to kind of listen to music that they like, or a bit more mainstream music ... so there's definitely a difference between what I listen to in private and what I listen to in public". Participant 5.

\subsubsection{Global relevance of Asian music}

This theme pertained to participants opinions about the place and value of Asian music/artists globally, especially among non-Asian individuals.

\subsubsection{Increasing media representation and acceptance of Asian-American artists}

Participants shared that they had observed more media coverage of Asian-American artists, and that they experienced pride and happiness in this increased media representation. For instance, Participant 4 reported,

"There was not much Asian representation in the US music industry, but I think things are slowly being shaken up with the rise of Asian artists... YouTube changed everything". Participant 4.

According to them, this was linked to increased acceptance and popularity of Asian artists. Notably, most participants shared the example of K-pop becoming a mainstream form of music in Western societies. For instance, Participant 2 claimed,

“...you see, like, huge global superstars like BTS and BLACKPINK really just being able to penetrate the American, and I'm sure, European market as well." Participant 2.

Participants also elaborated on how they were proud to see Asian-American artists in the music industry. They also expressed their willingness to support such artists in solidarity. When asked about why he mostly listened to Asian artists, Participant 1 responded,

"I think it has something to do with, uh, some subconscious, uh, you know, pride of AsianAmerican artists being successful or supporting Asian-American artists .. I just feel like supporting other Asian-Americans is something that is pretty easy to do, um, with music." Participant 1.

\subsubsection{Under-representation/stereotyping of Asian artists}

In contrast to the increasing acceptance and popularity expressed in the previous subtheme, some participants also opined that Asian artists continue to be underrepresented and undervalued in the American music industry. For instance, Participant 3 expressed his dissatisfaction with this underrepresentation and named specific artists who he felt were unfairly treated because of their Asian ethnicities.

"A lot of Asian-American artists are also very ignored in the media or ignored in the music scene. So we have, like, artists like Rina Sawayama, who released a great album but wasn't even nominated for a Grammy, and other artists who are just virtually ignored by the music community. So I think there just isn't any representation in the first place." Participant 3. 


\section{3-05 September $2021 \quad$ Prague, Czech Republic}

Even those who reported that the exposure to Asian music was increasing acknowledged that their media representations were inadequate or stereotypical. Participant 2 elaborated that although she saw an increase of Asian artists and songs being seen in American society, they were still sidelined from the true mainstream. She said,

“...any Asian artist that I would listen to is grouped into a specific subgenre of being Asian. It's very much like "Korean pop" or "anime music" or "Chinese drama soundtracks" and so, that doesn't get publicized mainstream anywhere, like when you go to the mall, or when you step outside." Participant 2.

\section{Discussion}

The present findings revealed two major aspects of the lived experiences of AsianAmerican youth in terms of their cultural identity and music preferences, within and outside the context of COVID-19. On one hand, their narratives revealed a sense of pride, identification, and acceptance of their Asian identity and of Asian artists/music. This went hand in hand with the seemingly desirable "model minority" epithet, the increasing awareness about the Asian culture in the US, and the acceptance and popularity of Asian artists globally. On the other hand, their narratives revealed negative experiences pertaining to the burden of the "model minority" view, discrimination, media stereotyping of Asians in general and of Asian artists specifically, increasing violence and negative perceptions against Asians owing to COVID-19, and the need to "fit in" to their peer group and the American society by altering their music choices. This juxtaposition would inevitably lead to a sense of straddling two spheres of their life, or as mentioned by Participant 3, "being between two different worlds".

What does this mean for youth who are in the process of discovering and establishing their identity? As mentioned in the literature review, adolescence and early adulthood (i.e., the period of youth) is already characterized by a constant struggle to establish one's identity. With a dual cultural identity of being American and Asian, the target population of this study already experiences substantial levels of identity conflict, as evidenced by their overarching feeling of not belonging to any one culture. This confusion regarding one's identity could be exacerbated by several experiences that the present participants shared.

First, the existence of subtle stereotypes and lack of acceptance of Asians in the US could contribute to a sense of insecurity about their Asian backgrounds. This would create a pressure on these adolescents to hide the "Asian" side of their identity. A typical example of this is the tendency to change one's choices according to the context. Participant 5 in the present study shared that he tended to listen to his chosen music when he was alone because it did not match the predominant choice of his peer group. This finding highlights the fact that AsianAmerican youth are aware about their conflicting identities and that they wish to resolve this conflict by accepting and enjoying their Asian culture. However, due to socio-cultural factors and pressures, it may not always be possible for them to do so. This suggest the need to provide them timely support as they pass through the stages of identity formation suggested by Marcia (1966).

Second, the present participants were aware of the "model minority" image of Asians in the US. More importantly, while they acknowledged that this perception had its advantages, they experienced the burden of having to excel in everything that they did. Further, they were perceptive of the fact that despite this seemingly positive stereotype, there were limitations to 


\section{3-05 September $2021 \quad$ Prague, Czech Republic}

the extent to which Asians were accepted in the American society. Participants reported that there was a glass ceiling that limited how much they could achieve in the American society.

Alternatively called as the "bamboo ceiling" (Hyun, 2005), the underrepresentation of Asians in leadership positions across several domains despite their educational and professional excellence has been widely reported in previous studies(Lee, 2019). This perceived glass/bamboo ceiling would inevitably influence the emerging identity and in-group behaviors of Asian-American youth. Participants also lamented about the lack of media coverage and credit to Asian artists despite their rich talent. Imaginably, this could be another confirmation of the glass ceiling phenomenon against Asians in the US.

Third, the participants reported a gradual increase in animosity towards Asians following the outbreak of COVID-19. While some acknowledged that subtle stereotypes and discrimination already existed in the American society, other felt that they had increased more recently. This view is also supported by several recent media reports of violence against Asians and by recent studies. For instance, an April 2021 survey conducted by the Pew Research Center revealed that $81 \%$ Asian individuals said that violence against Asians was increasing. Further, $45 \%$ of their participants had experienced at least one offensive incident since COVID19 outbreak (Ruiz et al., 2021). This is in stark contrast to the $20 \%$ individuals who reported having experienced discrimination in a 2012 survey conducted by the same organization (Pew Research Center, 2012).

During the identity-formation stage, when youth either experiment with different identities or take on socially-expected identities, such negative experiences and perceptions would either lead to resentment or embarrassment about their Asian identity or to strong negative feeling towards Americans and their own American identity. Further, the mental health repercussions of this conflict between whether to celebrate and showcase one's Asian identity or to hide it and fit into the image expected in the American society are obvious. Again, this highlights the need to provide counseling support and/or timely adult intervention during a stressful period of confusion.

In this context, the social function of music cannot be underplayed. As evidenced by several preceding studies, music choices act as a "badge" that individuals display to express their membership of a group (Dolfsma, 1999). Music preferences not only establish in- and out-group boundaries and behaviors, but they also facilitate the formation and sustenance of adolescent friendships (North \& Hargreaves, 1999; Selfhout et al., 2009). This would explain why the participants of the present study acknowledged that music helped them relate to their peers. Most of them also had a peer group that comprised Asian-American individuals, and they all had similar music choices. This tendency to gravitate towards individuals with similar backgrounds and tastes was also reported by Phinney (1990) and (Saether, 2008). Similarly, the Pew Research Center's 2012 Asian-American survey also revealed that more than $40 \%$ of the participants had a peer group that was predominantly of Asian-American composition. This role of music in creating a social image was so strong that the present participants mentioned that, even when their choices did not match those of their friends, they tended to listen to mainstream music to "fit in." Thus, music preferences and their function in expressing one's identity could also be influenced by peer pressure. Further, the pride associated with the increasing popularity of Asian artists in the mainstream music industry and the need to express solidarity toward them reported by the present participants is also related to the "identification" 
function of music. Together, these findings suggest the potential to use music as a medium to help Asian-American adolescents explore different aspects of both their cultures and enjoy the best of both worlds. This study also highlights the need to equip youth with the skills and abilities to withstand social pressure in establishing their own identity.

\section{Conclusion}

This mixed method study with focus on the lived experiences of Asian-American youth revealed the constant conflict between the dual identities of this group. It also highlighted the role of music in the life of young individuals, and the strong two-way relationship between music preferences and social factors. That is, on one hand, Asian-American youth's expression of their music preferences is influenced by social factors such as peers and group belongingness; on the other, their social image and group membership are themselves influenced by their choice in music. Together, these findings revealed a potential area of unmet needs of Asian-American youth, which could contribute to their mental health. Therefore, professionals working with these youth need to consider providing appropriate and timely support for Asian-American youth while they negotiate the perilous and vast ocean of identity formation.

\section{References}

Bleich, S., Zillmann, D., \& Weaver, J. (1991) Enjoyment and consumption of defiant rock music as a function of adolescent rebelliousness. Journal of Broadcasting and Electronic Media, 35, 351-366.

Budiman, A., \& Ruiz, N. G. (2021, April 29). Key facts about Asian Americans, a diverse and growing population. Pew Research Center. https://www.pewresearch.org/facttank/2021/04/29/key-facts-about-asian-americans/

Chen, J. A., Zhang, E., \& Liu, C. H. (2020). Potential impact of COVID-19-related racial discrimination on the health of Asian Americans. American Journal of Public Health, 110(11), 1624-1627.

Croucher, S. M., Nguyen, T., \& Rahmani, D. (2020). Prejudice toward Asian Americans in the COVID-19 pandemic: the effects of social media use in the United States. Frontiers in Communication, 5, 39.

Dolfsma, W. (1999). The consumption of music and the expression of values: a social economic explanation for the advent of pop music. American Journal of Economics and Sociology, 58, 1019-1046.

Erikson, E. H. (1968). Identity: Youth and crisis. Norton.

Fletcher, J. C. (2015). Creative engagement with music and adolescent identity work. In: J. Rosevear \& S. Harding (Eds.). Music: Educating for life. ASME XXth National Conference Proceedings (pp. 37-43). Australian Society for Music Education. https://search.informit.org/doi/10.3316/informit.650089864643071

Gregory, A. (1997). The roles of music in society: the ethnomusicological perspective. In D. J. Hargreaves and A. C. North (ed.), The social psychology of music (pp. 123-140). Oxford University Press. 
Hargreaves, D. J., North, A. C., \& Tarrant, M. (2006). Musical preference and taste in childhood and adolescence. In G.E. McPherson (Ed.), The child as musician: A handbook of musical development (pp. 135-154). Oxford University Press.

Hargreaves, D.J., \& North, A.C. (1997). The social psychology of music. In D. J. Hargreaves \& A. C. North (Eds.), The social psychology of music (pp. 1-21). Oxford University Press.

Hyun, J. (2005). Breaking the bamboo ceiling: Career strategies for Asians. HarperCollins.

Jung, S. (2021). The model minority myth on Asian Americans and its impact on mental health and the clinical setting. Asian American Research Journal, 1(1). https://escholarship.org/uc/item/2g78c205

Kim, P. Y. (2021). Internalized model minority myth, God representations, and mental health among Christian Asian Americans. Psychology of Religion and Spirituality. Advance online publication. https://doi.org/10.1037/rel0000435

Kirchler, E., Palmonari, A., \& Pombeni, M. L. (1993). Developmental tasks and adolescents' relationships with their family. In S. Jackson and H. Rodriguez-Tomé (Eds.), Adolescence and its social worlds (pp. 145-167). Lawrence Erlbaum.

Kistler, M., Rodgers, K. B., Power, T., Austin, E. W., \& Hill, L. G. (2010). Adolescents and music media: Toward an involvement-mediational model of consumption and self-concept. Journal of Research on Adolescence, 20, 616-630.

Lee, F. (2019). Asian American and Pacific Islander faculty and the bamboo ceiling: Barriers to leadership and implications for leadership development. New Directions For Higher Education, 186, 93-102. doi: 10.1002/he.20326

Lee, J., \& Zhou, M. (2014). From unassimilable to exceptional: The rise of Asian Americans and 'stereotype promise.'. New Diversities, 16(1), 7-22.

Lee, K.-Y., \& Joo, S.-H. (2005). The portrayal of Asian Americans in mainstream magazine ads: An update. Journalism \& Mass Communication Quarterly, 82, 654-671.

Lorenzo, M. K., Frost, A. K., \& Reinherz, H. Z. (2000). Social and emotional functioning of older Asian American adolescents. Child \& Adolescent Social Work Journal, 17, 289-304.

Marcia, J. (1966). Development and validation of ego-identity status. Journal of Personality and Social Psychology, 3, 551-558.

Marcia, J. (1980). Identity in adolescence. In J. Adelson (Ed.), Handbook of adolescent psychology (pp. 159-187). Wiley.

Miranda, D. (2013). The role of music in adolescent development: Much more than the same old song. International Journal of Adolescence and Youth, 18(1), 5-22.

Miranda, D., \& Claes, M. (2009). Music listening, coping, peer affiliation and depression in adolescence. Psychology of Music, 37, 215-233.

Moser, A., \& Korstjens, I. (2018). Series: Practical guidance to qualitative research. Part 3: Sampling, data collection and analysis. European Journal of General Practice, 24(1), 9-18.

North, A. C., \& Hargreaves, D. J. (1999). Music and adolescent identity. Music Education Research, 1(1), 75-92. 


\section{3-05 September $2021 \quad$ Prague, Czech Republic}

North, A. C., \& Hargreaves, D. J. (2008). The social and applied psychology of music. Oxford University Press.

North, A. C., Hargreaves, D. J., \& O'Neill, S. A. (2000). The importance of music to adolescents. British Journal of Educational Psychology, 70, 255-272. https://doi.org/10.1348/000709900158083

Palmonari, A., Pombeni, M. L., \& Kirchler, E. (1990). Adolescents and their peer groups: a study on the significance of peers, social categorization processes and coping with developmental tasks. Social Behaviour, 5, 33-48.

Park, J. H., Gabbadon, N. G., \& Chernin, A. R. (2006). Naturalizing racial differences through comedy: Asian, Black, and White views on racial stereotypes in Rush Hour 2. Journal of Communication, 56, 157-177.

Pew Research Center (2012, June 19). The rise of Asian Americans. Pew Research Center. https://www.pewresearch.org/social-trends/2012/06/19/the-rise-of-asian-americans/\#fnref12979-5

Phinney, J. S. (1990). Ethnic identity in adolescents and adults: Review of research. Psychological Bulletin, 108, 499-514.

Rentfrow, P. J., \& Gosling, S. D. (2006). Message in a ballad: The role of music preferences in interpersonal perception. Psychological Science, 17, 236-242.

Ruiz, N. G., Edwards, K., \& Lopez, M. H. (2021, April 21). One-third of Asian Americans fear threats, physical attacks and most say violence against them is rising. Pew Research Center. https://www.pewresearch.org/fact-tank/2021/04/21/one-third-of-asian-americans-fearthreats-physical-attacks-and-most-say-violence-against-them-is-rising/

Russell, P. A. (1997). Musical tastes and society. In D. J. Hargreaves and A. C. North (Eds.), The social psychology of music (141-158). Oxford University Press.

Saether, E. (2008). When minorities are the majority: Voices from a teacher/researcher project in a multicultural school in Sweden. Research Studies in Music Education, 30, 25-42.

Selfhout, M. H. W., Branje, S. J. T., ter Bogt, T. F. M., \& Meeus, W. H. J. (2009). The role of music preferences in early adolescents' friendship formation and stability. Journal of Adolescence, 32, 95-107.

Smith, D. W. (2018). Phenomenology. In E. N. Zalta (Ed.) The Stanford Encyclopedia of $\begin{array}{llll}\text { Philosophy } & \text { (Summer } & 2018 & \text { Edition). }\end{array}$ https://plato.stanford.edu/archives/sum2018/entries/phenomenology/

Suzuki, B. H. (2002). Revisiting the model minority stereotype: Implications for student affairs practice and higher education. New Directions for Student Service, 97, 21-32.

Taylor, C. R., Landreth, S., \& Bang, H.-K. (2005). Asian Americans in magazine advertising: Portrayals of the "model minority". Journal of Macromarketing, 25, 163-174.

United Nations Department of Economic and Social Affairs (n.d.) Definition of youth. Fact Sheet. https://www.un.org/esa/socdev/documents/youth/fact-sheets/youth-definition.pdf 
Urs, N. (2003). Music Preference Questionnaire (MPQ-R). https://www.musicandhealthlab.com/app/download/13808949035/MPQR_English+version.pdf?t=1515410609

Wu, C., Qian, Y., \& Wilkes, R. (2021). Anti-Asian discrimination and the Asian-white mental health gap during COVID-19. Ethnic and Racial Studies, 44(5), 819-835.

Yuen, N. W., Chin, C., Deo, M., Lee, J., \& Milman, N. (2005). Asian Pacific Americans in prime time: Lights, camera and little action. The National Asian Pacific American Legal Consortium.

Zhang, Q. (2010). Asian Americans beyond the model minority stereotype: The nerdy and the left out. Journal of International and Intercultural Communication, 3(1), 20-37. doi: $10.1080 / 17513050903428109$

Zhou, M. (2004). Are Asian Americans becoming “White?”. Contexts, 3(1), 29-37. 
Supplemental Table 1. Participants' characteristics.

Supplemental Table 2. Participants' music preferences

Note. All 1-4 ratings were with 1 as lowest to 4 as highest.

\begin{tabular}{|l|l|l|l|l|}
\hline Participant & Age category & Gender & Sub-ethnicity & $\begin{array}{l}\text { Geographical } \\
\text { location in the US }\end{array}$ \\
\hline Interviewee 1 & $15-17$ years & Male & Korean-Asian & West \\
\hline Interviewee 2 & $15-17$ years & Female & Chinese-Asian & West \\
\hline Interviewee 3 & $15-17$ years & Male & Korean-Asian & West \\
\hline Interviewee 4 & $18-24$ years & Male & Filipino-Asian & Midwest \\
\hline Interviewee 5 & $15-17$ years & Male & Filipino-Asian & West \\
\hline Interviewee 6 & $18-24$ years & Female & Vietnamese-Asian & Northeast \\
\hline Interviewee 7 & $15-17$ years & Male & Indian-Asian & Northeast \\
\hline
\end{tabular}




\begin{tabular}{|c|c|c|c|c|c|c|c|c|c|}
\hline $\begin{array}{l}\text { Participa } \\
\text { nt }\end{array}$ & $\begin{array}{l}\text { Importa } \\
\text { nce of } \\
\text { music } \\
\text { (rated } \\
\text { from 1- } \\
4 \text { ) }\end{array}$ & \begin{tabular}{|l} 
Enjoyi \\
$\mathrm{ng}$ \\
music \\
(rated \\
from \\
$1-4)$
\end{tabular} & $\begin{array}{l}\text { Numb } \\
\text { er of } \\
\text { hours } \\
\text { spent } \\
\text { listeni } \\
\text { ng to } \\
\text { music }\end{array}$ & $\begin{array}{l}\text { When do } \\
\text { you listen } \\
\text { to music? }\end{array}$ & $\begin{array}{l}\text { Most } \\
\text { preferr } \\
\text { ed } \\
\text { music } \\
\text { genre }\end{array}$ & $\begin{array}{l}\text { Top } 3 \\
\text { artists } \\
\text { (and their } \\
\text { genres) }\end{array}$ & $\begin{array}{l}\text { Ethnicit } \\
\mathrm{y} \text { of } \\
\text { most } \\
\text { artists } \\
\text { listened } \\
\text { to }\end{array}$ & $\begin{array}{l}\text { Ethnici } \\
\text { ty of } \\
\text { peer } \\
\text { group }\end{array}$ & $\begin{array}{l}\text { Extent of } \\
\text { matchin } \\
\mathrm{g} \text { music } \\
\text { preferen } \\
\text { ces with } \\
\text { peers } \\
\text { (rated } \\
\text { from 1- } \\
4 \text { ) }\end{array}$ \\
\hline $\begin{array}{l}\text { Intervie } \\
\text { wee } 1\end{array}$ & 4 & 4 & 2 & $\begin{array}{l}\text { During } \\
\text { leisure/ho } \\
\text { bby }\end{array}$ & $\begin{array}{l}\text { R\&B } \\
\text { and } \\
\text { Soul }\end{array}$ & $\begin{array}{l}\text { Mac } \\
\text { Ayres, } \\
\text { SZA, } \\
\text { Crush } \\
\text { (Alternati } \\
\text { ve, R\&B, } \\
\text { R\&B) }\end{array}$ & Asian & $\begin{array}{l}\text { All are } \\
\text { Asian- } \\
\text { Americ } \\
\text { an }\end{array}$ & 3 \\
\hline $\begin{array}{l}\text { Intervie } \\
\text { wee } 2\end{array}$ & 4 & 4 & 4 & $\begin{array}{l}\text { During } \\
\text { school } \\
\text { work }\end{array}$ & $\begin{array}{l}\text { Classic } \\
\text { al and } \\
\text { Opera }\end{array}$ & $\begin{array}{l}\text { The } \\
\text { Beatles, } \\
\text { Twice, } \\
\text { Bach } \\
\text { (60's, K- } \\
\text { pop, } \\
\text { classical) }\end{array}$ & $\begin{array}{l}\text { Caucasi } \\
\text { an }\end{array}$ & Mixed & 3 \\
\hline $\begin{array}{l}\text { Intervie } \\
\text { wee } 3\end{array}$ & 4 & 4 & 4 & $\begin{array}{l}\text { During } \\
\text { leisure/ho } \\
\text { bby }\end{array}$ & $\begin{array}{l}\text { R\&B } \\
\text { and } \\
\text { Soul }\end{array}$ & $\begin{array}{l}\text { BlackPin } \\
\mathrm{k}, \quad \mathrm{NF}, \\
\text { Agust D } \\
\text { (Kpop, } \\
\text { rap, K } \\
\text { hip-hop) }\end{array}$ & Asian & $\begin{array}{l}\text { All are } \\
\text { Asian- } \\
\text { Americ } \\
\text { an }\end{array}$ & 3 \\
\hline $\begin{array}{l}\text { Intervie } \\
\text { wee } 4\end{array}$ & 4 & 4 & 4 & $\begin{array}{l}\text { During } \\
\text { leisure/ho } \\
\text { bby }\end{array}$ & Pop & $\begin{array}{l}\text { Beatles, } \\
\text { Black } \\
\text { Pink, } \\
\text { Tchaikov } \\
\text { ski } \\
\text { (60's, K- } \\
\text { pop, } \\
\text { classical) }\end{array}$ & Asian & $\begin{array}{l}\text { All are } \\
\text { Asian- } \\
\text { Americ } \\
\text { an }\end{array}$ & 3 \\
\hline $\begin{array}{l}\text { Intervie } \\
\text { wee } 5\end{array}$ & 4 & 4 & 4 & $\begin{array}{l}\text { During } \\
\text { leisure/ho } \\
\text { bby }\end{array}$ & $\begin{array}{l}\text { R\&B } \\
\text { and } \\
\text { Soul }\end{array}$ & $\begin{array}{l}\text { Pearl } \\
\text { Jam, } \\
\text { Justin } \\
\text { Bieber, } \\
\text { Kanye } \\
\text { West } \\
\text { (Alternati } \\
\text { ve, R\&B, } \\
\text { R\&B) }\end{array}$ & $\begin{array}{l}\text { Caucasi } \\
\text { an }\end{array}$ & $\begin{array}{l}\text { All are } \\
\text { non- } \\
\text { Asian- } \\
\text { Americ } \\
\text { an }\end{array}$ & 2 \\
\hline $\begin{array}{l}\text { Intervie } \\
\text { wee } 6\end{array}$ & 4 & 4 & 3 & $\begin{array}{l}\text { During } \\
\text { leisure/ho } \\
\text { bby }\end{array}$ & $\begin{array}{l}\text { Classic } \\
\text { al and } \\
\text { Opera }\end{array}$ & $\begin{array}{l}\text { Bach, } \\
\text { Mozart, } \\
\text { Chopin }\end{array}$ & $\begin{array}{l}\text { Caucasi } \\
\text { an }\end{array}$ & $\begin{array}{l}\text { All are } \\
\text { non- } \\
\text { Asian- }\end{array}$ & 3 \\
\hline
\end{tabular}




\begin{tabular}{|l|l|l|l|l|l|l|l|l|l|}
\hline & & & & & $\begin{array}{l}\text { (Classical } \\
\text { ) }\end{array}$ & & $\begin{array}{l}\text { Americ } \\
\text { an }\end{array}$ & \\
\hline $\begin{array}{l}\text { Intervie } \\
\text { wee 7 }\end{array}$ & 4 & 4 & 2 & $\begin{array}{l}\text { During } \\
\text { school } \\
\text { work }\end{array}$ & Pop & $\begin{array}{l}\text { Frank } \\
\text { Ocean, } \\
\text { David } \\
\text { Guetta, } \\
\text { Justin } \\
\text { Bieber } \\
\text { (Alternati } \\
\text { ve, R\&B, } \\
\text { R\&B) }\end{array}$ & $\begin{array}{l}\text { Caucasi } \\
\text { an }\end{array}$ & $\begin{array}{l}\text { All are } \\
\text { Asian- } \\
\text { Americ } \\
\text { an }\end{array}$ & \\
& & & & & & & & \\
\hline
\end{tabular}

